\title{
Analisis Produktivitas pada Pendapatan PT BMT OPPO Manufacturing Indonesia Terhadap Penjualan Smartphone OPPO pada Tahun 2019-2021
}

\author{
Yuni Nuraeni ${ }^{1}$, Martasya ${ }^{2^{*}}$, Anisah Aufa $^{3}$ \\ Prodi Manajemen FEB Universitas International Batam \\ nuraeniyuni30@gmail.com, 2041090.martasya@uib.edu, anisahaufa9@gmail.com
}

*Corresponding Author

Diajukan : 15 Desember 2021

Disetujui : : 1 Januari 2022

Dipublikasi : 9 Januari 2022

\begin{abstract}
The Covid-19 pandemic has created a new behavior for the people of Indonesia, all activities have drastically changed to all digital. This causes the need for electronics to increase. Sales of smartphones, especially Oppo produced by PT BMT Oppo Manufacturing Indonesia, also felt its impact on the level of productivity, efficiency and income. Productivity is optimizing the use of resources in the form of human and financial resources. Income efficiency contains financial information which is an important part and must be given more attention because it involves the survival of the company. The purpose of the "research/mini paper project/paper (deck adjusted) is to determine the performance conditions and the role of productivity, efficiency and income as well as their influence on the policy formulation of PT BMT Oppo Manufacturing Indonesia. The author concludes that the sales of PT BMT Oppo Manufacturing Indonesia in 2019-2021 fluctuated, namely up and down which affected its income. The strategy is to maximize revenue by making new breakthroughs and creating various trends so as not to miss the trend and to be able to compete with competitors.
\end{abstract}

Keywords: OPPO, Income, Productivity

\section{PENDAHULUAN}

Indonesia dengan segala potensinya ditargetkan oleh banyak industri elektronik luar negeri sebagai pangsa pasar yang besar dan tak jarang industri elektronik tersebut memusatkan beberapa kegiatan produksinya di Indonesia mengingat negeri ini memiliki sumber daya manusia yang banyak dan murah serta lahan yang luas untuk membangun perusahaan maupun industri. Tidak salah jika industri elektronik bersama industri logam, mesin, dan industri kedokteran menempati peringkat pertama dalam "5 Besar Nilai Investasi Sektor Industri" dan menempati peringkat kelima dalam "6 Sektor Industri dengan Nilai Ekspor Terbesar" (Kemenperin, 2019). Besarnya perkembangan industri sektor elektronik ini dipacu pula oleh meningkatnya kebutuhan elektronik masyarakat Indonesia pasca pandemi COVID-19 memasuki negeri ini. Sebagian besar sektor kehidupan diubah menjadi kegiatan dalam jaringan, sehingga kebutuhan masyarakat akan alat komunikasi elektronik seperti laptop, handphone, dan alat komunikasi elektronik penunjang lainnya menjadi meningkat. Perilaku masyarakat ini akan memberikan pengaruh secara langsung kepada tingkat produktivitas, efisiensi, dan pendapatan perusahaan elektronik terkait, salah satunya yaitu PT BMT OPPO Manufacturing Indonesia.

Produktivitas merupakan prinsip rasional mengenai pengoptimalan penggunaan sumber daya (Sukirno, 2012). Berdasarkan pengertian produktivitas ini dapat dipahami bahwa produktivitas dapat diukur dari banyaknya jumlah produk yang dihasilkan maupun dari sisi keuangannya. Secara tersirat, pengertian produktivitas juga berarti efisien dalam menggunakan 
sumbar daya manusia maupun keuangan. Tentu menyelaraskan tingkat produktivitas, efisiensi, dan pendapatan tidaklah mudah dan selalu memberikan tantangan dalam setiap periodenya, terutama dalam hal perumusan kebijakan untuk mencapai ketiga hal tersebut.

Kebijakan privat merupakan tindakan yang dilakukan oleh seseorang atau lembaga swasta dan tidak bersifat memaksa kepada orang atau lembaga lainnya (Pantjar Simatupang, 2003). Oleh karena itu, setiap perusahaan swasta memiliki kebijakan yang berbeda tertgantung pada visi, misi, dan karakter perusahaan tersebut. Menurut Suharno (2003), faktor-faktor yang mempengaruhi perumusan kebijakan yakni pengaruh tekanan-tekanan dari luar, kebiasaan lama, sifat-sifat pribadi, pengaruh dari kelompok luar, dan keadaan masa lalu. Informasi keuangan, analisa performa tiap bagian perusahaan, dan proyeksi pasar serta arus kas perusahaan juga memiliki peran dalam menentukan kebijakan perusahaan terkait.

Berdasarkan pemaparan diatas, maka penulis tertarik untuk melakukan penelitian terkait "Analisis Produktivitas pada Pendapatan PT BMT Oppo Manufacturing Indonesia Terhadap Penjualan Smartphone Oppo Pada Tahun 2019-2021".

\section{METODE}

Penelitian ini dengan menggunakan data kuantitatif yaitu data-data yang dinyatakan dalam bentuk angka. Adapun jenis dan sumber data yang digunakan pada penelitian ini merupakan data sekunder yaitu data yang didapatkan dari pihak lain dalam bentuk publikasi atau telah jadi. Populasi pada penelitian ini yaitu PT BMT OPPO Manufacturing Indonesia. Pada penelitian ini metode yang digunakan untuk mengambil sampel dengan menggunakan purposive sampling, yaitu teknik untuk menentukan sample dengan pertimbangan tertentu. Sample pada penelitian ini yaitu dari lima merek smartphone yang ada di Indonesia, seperti Oppo, Samsung, Vivo, Apple, dan Xiaomi.

Untuk memperoleh hasil dari perbandingan pada Smartphone OPPO dengan merek smartphone lainnya dengan menggunakan periode 3 tahun yaitu tahun 2019-2021.

\section{HASIL}

Penjualan Smartphone di saat pademi Covid-19 terjadi peningkatan, dikarenakan masyarakat Indonesia membutuhkan smartphone untuk melakukan kegiatan atau aktivitas secara online, seperti bekerja dan belajar dirumah.

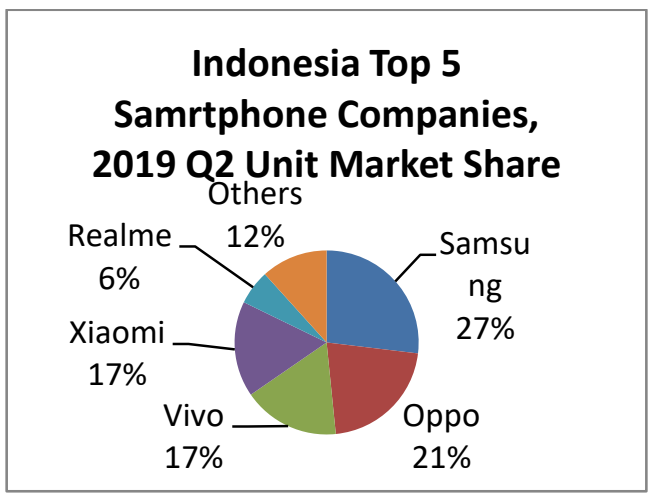

Gambar 1.

Presentase Market Share Smartphone 2019 Q2

Pada tahun 2019 Q2 OPPO meraih peringkat ke dua dengan presentase 21\% setelah samsung. Adapun masalah yang dihadapi OPPO yaitu kelangkaan chip global, namun vendor handphone OPPO ini belum ada niat dalam menaikkan harga produknya yang dijual di Tanah Air (Indonesia). Salah satu dalam menghadapi kelangkaan tersebut perusahaan OPPO menjalin kerja sama dengan produsen OPPO, demi menjaga rantai supply ke OPPO. 
Tabel 1.

Presentase Perusahaan Smartphone Q4 2019-2020

\begin{tabular}{llllll}
\hline Perusahaan & $\begin{array}{l}\text { Jumlah } \\
\text { Pengiriman } \\
\text { Q4 2020 }\end{array}$ & $\begin{array}{l}\text { Pangsa } \\
\text { Pasar } \\
\text { Q4 } \\
2020\end{array}$ & $\begin{array}{l}\text { Jumlah } \\
\text { Pengiriman } \\
\text { Q4 2019 }\end{array}$ & $\begin{array}{l}\text { Pangsa } \\
\text { Pasar }\end{array}$ & Pertumbuhan \\
\hline Apple & 90,1 & $23,4 \%$ & 73,8 & $19,9 \%$ & $22,2 \%$ \\
\hline Samsung & 73,9 & $19,1 \%$ & 69,5 & $18,8 \%$ & $6,2 \%$ \\
\hline Xiaomi & 43,3 & $11,2 \%$ & 32,8 & $8,9 \%$ & $32 \%$ \\
\hline Oppo & 33,8 & $8,8 \%$ & 30,6 & $8,3 \%$ & $10,7 \%$ \\
\hline Huawei & 32,3 & $8,4 \%$ & 56,2 & $15,2 \%$ & $4,24 \%$ \\
\hline Lain-lain & 112,4 & $29,1 \%$ & 107,1 & $28,9 \%$ & $5 \%$ \\
\hline Total & 385,9 & $100 \%$ & 369,9 & $100 \%$ & $4,3 \%$ \\
\hline
\end{tabular}

Dari tabel di atas OPPO pada tahun 2019 dengan jumlah pengiriman Q4 2019 sebesar 30,6, dan pangsa pasar sebesar 8,3\%, kemudian terjadi kenaikan pada tahun 2020 dengan jumlah pengiriman Q4 sebesar 33,8 dan pangsa pasar sebesar 8,8\%. Maka dari itu OPPO mengalami pertumbuhan sebesar $10,7 \%$.

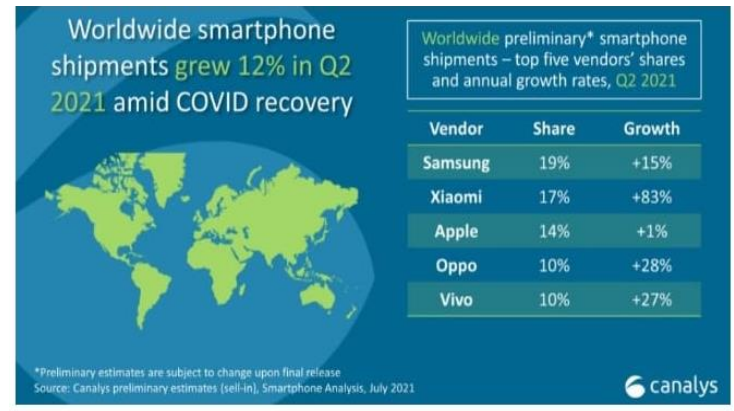

Gambar 2.

Lima Peringkat Smartphone di Dunia Q2 2021

Berdasarkan market share menurut Canalys Oppo pada tahun 2021 Q2 berada di peringkat ke-4 setelah Apple dengan market share 10\%, dan Growth $+28 \%$. OPPO telah bertransformasi dari smartphone yang bagus saat digunakan selfie. Sebelumnya OPPO memfokuskan dalam mengembangkan kamera depan, akan tetapi kini yang menjadi perhatian OPPO adalah kamera belakang. Resolusi tinggi serta fitur kamera yang menarik menajdi alasan konsumen untuk membeli smartphone OPPO tersebut.

\section{PEMBAHASAN}

Smartphone OPPO memiliki tiga seri yaitu Find X, Reno, dan Seri A. OPPO yang berseri Find $\mathrm{X}$ ditujukan untuk menengah ke atas karena harga yang ditawarkan cukup tinggi, dan spesifikasi dari seri Find $X$ ini sekelas atau setara dengan Handphone Flagship pada umumnya, akan tetapi yang menjadi fokus dari OPPO seri Find X ini yaitu layar dan kamera. Kemudian untuk seri Reno sasaran konsumennya yaitu kelas menengah, fitur kamera lebih inovatif, dan performanya menjadi suatu kebanggaan, selain itu Reno juga memiliki desain yang mewah. Sedangkang untuk seri A sasaran konsumennya yaiitu untuk kelas menengah ke bawah hingga pemula, karena harga yang ditawarkan relatif terjangkau oleh konsumen.

Demi memaksimalkan pendapatan perusahaan OPPO terus meningkatkan kualitas produknya dengan cara membuat produk baru yang lebih menarik, membuat iklan di televisi, koran ataupun sosial media, dan bekerja sama dengan brand ambassador untuk meningkatkan 
penjualan seperti Dian Sastrowardoyo, Chelsea Islan, Nicholas Saputra, Reza Rahardian, dan lain-lain. Selain itu teknik marketing yang baik juga penting dalam meningkatkan penjualan dan pendapatan seperti memberikan diskon atau potongan harga untuk produk tertentu supaya konsumen tertarik dalam membeli produk tersebut.

Salah satu kebijakan dari perusahaan OPPO yaitu kebijakan garansi resmi, demi memberikan layanan yang baik untuk konsumen dengan tujuan dapat terhindar dari rusaknya perangkat ataupun masalah garansi seperti garansi smartphone OPPO selama 12 bulan (1 tahun).

\section{KESIMPULAN}

Berdasarkan pada pembahasan di atas, dapat ditarik kesimpulan bahwa perusahaan OPPO pada tahun 2019-2021 sering terjadi penurunan dan kenaikan terhadap penjualan, dan hal tersebut berpengaruh pada pendapatannya. Demi memaksimalkan pendapatan perusahaan OPPO membuat kebijakan seperti meningkatkan kualitas produk, fitur, desain serta spesifikasi, teknik marketing yang baik juga sangat penting terhadap penjualan prosuk, selain itu perusahaan OPPO bekerja sama dengan brand ambassador untuk mendongkrak pendapatannya, dan memberikan potongan harga pada produk tertentu.

\section{SUMBER RUJUKAN}

Adi,F. R. (2021). Apple Raja Ponsel di Q4, Tapi Samsung Peguasa 2020. Www.Inet.Detik.Com. https://inet.detik.com/business/d-5354719/apple-raja-ponsel-di-q4-tapi-samsung-sangpenguasa-2020B

Dasar, K., \& Prosedur, D. A. N. (2017). Analisis Kebijakan: Konsep Dasar dan Prosedur Pelaksanaan. Analisis Kebijakan Pertanian, 1(1), 1-23. https://doi.org/10.21082/akp.v1n1.2003.1-23

Dewa Bagus Nugraha Windusara \& Kusuma A.A. Gd Agung Artha. (2015). PENGARUH BAURAN PROMOSI TERHADAP KEPUTUSAN PEMBELIAN OPPO SMARTPHONE. Arthavidya Jurnal Ilmiah Ekonomi, 4(12), 101-120. https://ojs.unud.ac.id/index.php/Manajemen/article/download/14930/11193

Gama, prabowo. (2021). Penjualan Smartphone Xiaomi di Q2 2021 Meningkat Drastis, Apple Kalah! Www.Nextren.Grid.Id. https://nextren.grid.id/amp/012792316/penjualansmartphone-xiaomi-di-q2-2021-meningkat-drastis-apple-kalah

Bagus Nugraha Windusara \& Kusuma A.A. Gd Agung Artha. (2015). PENGARUH BAURAN PROMOSI TERHADAP KEPUTUSAN PEMBELIAN OPPO SMARTPHONE. Arthavidya Jurnal Ilmiah Ekonomi, 4(12), 101-120. https://ojs.unud.ac.id/index.php/Manajemen/article/download/14930/11193

Kemetrian Perindustrian. (2019). Laporan Kinerja Kementrian Perindustrian Tahun 2015-2019. Kementerian Perindustrian, 1-128. https://kemenperin.go.id/download/21250/LaporanKinerja-Kementerian-Perindustrian-2018

Nova, R. (2018). Pengaruh Harga, Citra Merek, dan Advertising Terhadap Keputusan Pembelian Produk Smartphone Oppo F1 Selfie Expert(Study Kasus Pada Mahasiswa/i Fakultas Ekonomi dan Bisnis Universitas Sumatera Utara). 44-48.

Paputungan, A. R., Bachri, S., \& Ponirin, P. (2021). Pengaruh Atribut Produk Dalam Mendorong Niat Beli Smartphone Oppo Di Kota Palu. Jurnal Ilmu Manajemen Universitas Tadulako (JIMUT), 7(1), 021-029. https://doi.org/10.22487/jimut.v7i1.214

Soevyakto, Bemby, B., \& Bashir, dan A. (2014). Ekonomi Pembangunan Syariah. Rajawali Press, 1(2), 141-160. 